\title{
Efek Pemberian Air Rebusan Kunyit (Curcuma domestica) dan Daun Sirih (Piper betle linn) di dalam Air Minum dan Kombinasi Keduanya terhadap Bobot Karkas dan Lemak Abdominal Ayam Broiler
}

\author{
Effect of Inclusion of Turmeric (Curcuma domestica) and Betel leaf (Piper betle Linn) and \\ their Combinations in on Final Body Weight, Carcass Weight and Fat Abdomimal in Broiler \\ Chicken
}

\author{
M. P. Alhadi, E. Erwan*, Elviriadi dan M. Rodiallah \\ Program Studi Peternakan, Fakultas Pertanian dan Peternakan, Universitas Islam Negeri Sultan Syarif \\ Kasim Riau, Jl. H.R. Soebrantas No.155 KM.15 Simpang Baru Panam Pekanbaru 28293, Indonesia \\ *Corresponding Author : erwan edi@yahoo.com
}

\begin{abstract}
Turmeric (Curcuma domestica) and Betel leaf (Piper betle Linn) have beneficial effect as herbal plants which induced antioxidant activities in digestive systems. The aims of present study was to examine the effect of turmeric or betel leaf solution and their combination on final body weight, carcass weight, carcass percentage and abdominal fat in broiler chickens. The total eighty broiler chickens were kept from DOC until 28 days old while the treatments were started when chicks at 8 days old. The research design used was a completely randomized design (CRD), consisted 4 treatments and 5 replications, namely P0 (pure water), P1(25\% turmeric solution water plus 1 liter of water), P2 ( $25 \%$ betel leaf solution water plus 1 liter of water), P3(25\% mixing of turmeric and betel leaf solution plus 1 liter of water). Parameters measured including final body weight, carcass weight, carcass percentage and abdominal fat. The results of showed that there was a significant effect $(\mathrm{P}<0.05)$ among treatments on the percentage of carcass but no significant $(\mathrm{P}>0.05)$ effect was found on final body weight, abdominal fat and percentage of abdominal fat. It is concluded that the inclusion of turmeric or betel leaf or mixing these solutions at $25 \%$ may not alter final body weight, carcass weight, carcass percentage and failed to decrease abdominal fat weight, and the percentage of abdominal fat in broiler chickens.
\end{abstract}

Key words: turmeric, betel leaf, broiler, final body weight, carcass, abdominal fat

\begin{abstract}
ABSTRAK
Kunyit (Curcuma domestica) dan daun sirih dapat memberikan manfaat sebagai tanaman herbal yang dapat merangsang aktivitas antioksidan khususnya didalam organ pencernaan. Tujuan penelitian ini adalah untuk mengukur pengaruh pemberian rebusan kunyit atau daun sirih, serta campuran keduanya terhadap bobot badan akhir, bobot karkas, persentase karkas, lemak abdominal dan persentase lemak abdominal ayam broiler. Jumlah ayam broiler yang digunakan adalah sebanyak 80 ekor dan pemberian perlakuan dimulai ayam umur 7 sampai 28 hari. Penelitian ini menggunakan Rancangan Acak Lengkap (RAL) yang terdiri atas 4 perlakuan dan 5 ulangan yakni P0 (air biasa), P1 (air larutan kunyit 25\% di tambah 1 liter air), P2 (air larutan daun sirih 25\% di tambah 1 liter air), P3 (campuran air larutan kunyit dan air larutan daun sirih 25\% di tambah 1 liter air). Parameter yang diukur pada penelitiian ini meliputi bobot badan akhir, bobot karkas, persentase karkas, lemak abdominal dan persentase lemak abdominal. Hasil yang diperoleh dalam penelitian ini adalah bahwa perlakuan memberikan pengaruh yang nyata $(\mathrm{P}<0,05)$ terhadap persentase karkas namun tidak berpengaruh nyata $(\mathrm{P}>0,05)$ terhadap bobot badan akhir, bobot karkas, lemak abdominal dan persentase lemak abdominal. Dapat disimpulkan bahwa pemberian larutan kunyit atau air daun sirih atau campuran larutan kunyit dan larutan daun sirih pada level $25 \%$ didalam air minum belum memberikan perubahan terhadap bobot badan akhir, bobot karkas dan persentase karkas serta belum mampu meminimalkan bobot lemak abdominal dan persentase lemak abdominal ayam broiler.
\end{abstract}

Kata kunci: kunyit, daun sirih, broiler, bobot badan akhir, karkas, lemak abdominal.

\section{PENDAHULUAN}

Salah satu komoditas unggulan sebagai penyumbang protein hewani asal ternak adalah ayam ras pedaging atau yang dikenal dengan ayam broiler. Meningkatnya konsumsi daging ayam broiler oleh masyarakat dewasa ini berdampak semakin meningkatnya perkembangan ayam broiler. Guna melindungi kesehatan ayam broiler dan pemacu pertumbuhan, pada umumnya peternak menggunakan antibiotik sebagai feed additive. 
Namun demikian, antibiotik yang dikonsumsi oleh unggas tidak diekresikan dengan sempurna sehingga sebagian mengendap didalam jaringan tubuh ayam dan dapat berdampak negatif terhadap kesehatan manusia yang mengkonsumsinya (Yuningsih, 2004). Disisi lain, masyarakat saat ini sudah meningkat tingkat kesadarannya terhadap pangan yang sehat. khususnya daging ayam broiler yang memiliki kualitas menurut acuan standar aman, sehat, utuh, dan halal (ASUH). Oleh karena itu penggunaan antibiotik tersebut sedapat mungkin untuk dihindari atau dikurangi. Salah satu alternatif sumber bahan herbal yang dapat dijadikan pengganti feed aditif adalah ekstrak kunyit dan rebusan daun sirih. Keunggulan pemberian zat aditif melalui air minum dapat memberikan respon yang lebih cepat dibandingkan melalui ransum.

Peranan kurkumin yang dikandung didalam kunyit adalah dapat merangsang dinding kantung empedu untuk mensekresikan cairan empedu sekaligus menstimulasi keluarnya getah pankreas yang mengandung beberapa enzim seperti lipase, amilase, dan protease guna meningkatkan pencernaan lemak, karbohidrat, dan protein (Rukmana, 1994). Kondisi tersebut akan menyebabkan proses pencernaan ayam broiler lebih baik sehingga kecernaan ransum akan meningkat dan mengakibatkan saluran pencernaan ayam broiler lebih cepat kosong dan pada akhirnya konsumsi ransum broiler akan meningkat. Penelitian sebelumnya (Tantalo, 2009) dilaporkan bahwa menujukkan bahwa pemberian kunyit (Curcuma domestica) melalui air minum memberikan efek positif terhadap dua strain ayam broiler yakni strain Lohmann dan CP 707. Kunyit yang telah diolah menjadi bentuk tepung, memiliki kandungan kimia berupa kurkuminoid yang berbentuk kurkumin. Adapun fungsi kurkumin yakni meningkatkan fungsi organ-organ khususnya organ pencernaan pada ayam broiler dengan memberikan rangsangan kepada dinding kantong empedu untuk mensekresikan cairan empedu dan merangsang keluarnya getah pankreas yang mengandung enzim amilase, lipase dan protease sehingga meningkatkan pencernaan zat makanan seperti karbohidrat, lemak dan protein. Selain itu, peran minyak atsiri yang terdapat didalam kunyit juga dapat mempercepat laju pengosongan isi lambung (Adi, 2009).

Beberapa keunggulan daun sirih (Piper betle) adalah memiliki kandungan minyak atsiri, polifenol flavonoid, tanin, dan beberapa metabolit sekunder lainnya seperti estragol, eugenol, dan betle phenol. Selain itu, didalam minyak atsiri terkandung karvakol yang bersifat anti jamur. Menurut Mahendra (2005) bahwa manfaat flavanoid dan polifenol adalah sebagai, anti inflamasi, antioksidan dan anti diabetik sedangkan tanin dapat berperan untuk menyembuhkan diare serta membantu mengatasi gangguan pencernaan Penelitian sebelumnya (Sudrajat et al., 2015) melaporkan bahwa pemberian larutan sirih 10 $\mathrm{ml} / \mathrm{L}$ air minum dapat meningkatkan energi metabolis dan retensi nitrogen yang terbaik pada ayam broiler. Namun demikian laporan tentang pengaruh penambahan campuran laurtan daun kunyit dan daun sirih belum pernah dilaporkan. Berdasarkan latar belakang tersebut, penulis melakukan penelitian tujuan untuk mengidentifikasi pengaruh pemberian air rebusan kunyit atau daun sirih dan kombinasi keduanya di dalam air minum terhadap bobot badan akhir, bobot karkas, persentase karkas dan bobot lemak abdominal dan persentase bobot lemak abdominal ayam broiler. Hipotesis dari penelitian ini adalah pemberian laruran daun kunyit atau daun sirih atau kombinasi keduanya berpengaruh terhadap paramater yang diukur.

\section{MATERI DAN METODE}

\section{Waktu dan tempat penelitian}

Lokasi penelitian ini adalah di Laboratorium Produksi Ternak dan Laboratorium UIN Agriculture Research and Development Station (UARDS), Fakultas Pertanian dan Peternakan UIN Sultan Syarif Kasim Riau, Pekanbaru.

\section{Alat Bahan penelitian}

Beberapa peralatan yang digunakan pada penelitian ini meliputi kandang ayam broiler berjumlah 20 unit, berukuran $1 \times 1 \times 0,5 \mathrm{~m}$ (panjang $\mathrm{x}$ lebar $\mathrm{x}$ tinggi) dan tiap unit kandang terdiri dari 4 ekor ayam. Selain itu, sebagai pemanas dan penerang digunakan lampu pijar 40 watt, tempat ransum, gelas ukur, tempat air minum, ember, timbangan digital, tempat untuk merebus daun sirih, saringan, kompor dan alat tulis. Ternak yang digunakan adalah day old chick (DOC) ayam broiler yang dipelihara mulai umur 1 hari sampai hari ketujuh sedangkan perlakuan penelitian dimulai ayam berumur $8-28$ hari dengan total 80 ekor dengan rataan bobot badan \pm 168 g/ekor. Adapun bahan herbal yang dicampurkan dalam air minum adalah rimpang kunyit dan daun sirih. 


\section{Ransum}

Ransum komersial yang digunakan adalah Vivo 311 untuk periode starter dan Vivo 512 periode finisher. Pemberian ransum diberikan secara ad libitum. Komposisi nutrisi ransum dapat dilihat pada Tabel 1.

Tabel 1. Komposisi Nutrisi Ransum Komersial

\begin{tabular}{lll}
\hline Zat Nutrisi & \multicolumn{2}{c}{ Jenis Ransum } \\
\hline & Starter (\%) & Finisher (\%) \\
\hline Protein & $21,0-22,0$ & $19,5-20,5$ \\
Abu & Max 8,0 & Max 8,0 \\
Lemak & Min 4,3 & Min 4,5 \\
Serat Kasar & Max 6,0 & Max 6,0 \\
Kalsium & Min 0,9 & Min 0,9 \\
Phosphor & Min 0,6 & Min 0,6
\end{tabular}

Sumber : PT. Charoen Pokphand Indonesia (2014).

\section{Air minum}

Air minum yang digunakan dalam penelitian berupa air biasa yang diberikan secara ad libitum ketika ayam broiler berumur $1-7$ hari tanpa perlakuan, sedangkan umur $8-28$ hari diberikan larutan kunyit atau larutan daun sirih atau campuran larutan kunyit dan larutan daun sirih sesuai dengan perlakuan. Adapun tahapan dalam membuat larutan kunyit yang dilakukan adalah sebagai berikut 1) mengambil bagian rimpang kunyit sebanyak $250 \mathrm{~g}, 2$ ) memotong rimpang kunyit dengan ukuran $3 \mathrm{~cm}, 3$ ) menumbuk potongan kunyit sampai halus, 4) memasukkan tumbukan kunyit kedalam dandang dengan berisi air 1 liter dan merebusnya selama 15 menit dan 5) menyaring/mengambil air rebusan kunyit sebanyak $25 \%$. Tahapan dalam membuat larutan daun sirih adalah sebagai berikut: 1) mengambil daun sirih sebanyak $250 \mathrm{~g}, 2$ ) memotong daun sirih dengan ukuran $2 \mathrm{~cm}, 3$ ) memasukkan potongan daun sirih kedalam dandang berisi 1 liter air dan merebus daun sirih selama 15 menit, 4) menyaring/mengambil air rebusan daun sirih sebanyak $25 \%$. Untuk campuran larutan kunyit dan larutan daun sirih dilakukan dengan langkah sebagai berikut: 1) mengambil bagian rimpang kunyit sebanyak 125 g, 2) mengambil daun sirih sebanyak $125 \mathrm{~g}, 3$ ) memotong rimpang kunyit dengan ukuran $3 \mathrm{~cm}$ dan menumbuk potongan kunyit sampai halus, 4) memotong daun sirih dengan ukuran $2 \mathrm{~cm}, 5$ ) memasukkan tumbukan kunyit dan potongan daun sirih kedalam dandang berisi 1 liter air kemudian merebusnya selama 15 menit dan 6) menyaring mengambil air rebusan tersebut sebanyak $25 \%$.

\section{Metode penelitian}

Metode penelitian dilakukan secara eksperimen dengan menggunakan Rancangan Acak Lengkap (RAL) yang terdiri atas 4 perlakuan dan 5 ulangan. Perlakuan terdiri atas :

P1 : Air biasa (kontrol)

P2 : Air larutan kunyit 25\%

P3 : Air larutan daun sirih 25\%

P4 : Campuran air larutan kunyit dan air larutan daun sirih $25 \%$

\section{Analisis data}

Data dianalisis dengan menggunakan analis sidik ragam sesuai dengan Rancangan Acak Lengkap (RAL). Apabila ada perbedaan yang nyata, maka dilanjutkan dengan uji Duncan`s Multiple Range Test.

\section{HASIL DAN PEMBAHASAN}

\section{Bobot badan akhir}

Rataan persentase bobot akhir ayam broiler yang diberi larutan kunyit (Curcuma domestica) dan daun sirih (Piper betle) serta kombinasi keduanya dalam air minum ditampilkan Tabel 2. Menurut hasil analisis sidik ragam diperoleh bahwa perlakuan pemberian larutan perlakuan tidak memberikan pengaruh nyata $(\mathrm{P}>0,05)$ terhadap bobot badan akhir ayam broiler. Kisaran rata-rata bobot badan akhir pada penelitian ini adalah 1208,10 g/ekor dan 1220,90 g/ekor.

Tabel 2. Rataan bobot badan akhir ayam broiler umur 28 hari yang diberi larutan kunyit atau daun sirih atau kombinasi keduanya (g/ekor)

\begin{tabular}{ll}
\hline Perlakuan (\%) & Bobot Badan Akhir \\
\hline Air biasa (Kontrol) (P0) & $1208,10 \pm 24,12$ \\
Air dengan LK 25\% (P1) & $1209,63 \pm 26,90$ \\
Air dengan LS 25\% (P2) & $1220,90 \pm 29,39$ \\
Air dengan LK dan LS 25\% (P3) & $1212,60 \pm 19,65$ \\
\hline
\end{tabular}

Keterangan: - LK $=$ Larutan Kunyit, LS = Larutan Sirih

- Data yang ditampilkan adalah Rataan \pm Standar Deviasi. 
Hasil penelitian ini berbeda dengan yang dilaporkan oleh Tantalo (2006) bahwa penambahan kunyit dalam air minum dengan dosis $10-20 \mathrm{~g} / \mathrm{l}$ dapat meningkatkan pertambahan bobot badan ayam broiler. Penelitian lanjutan oleh Tantalo et al (2010) juga melaporkan bahwa pemberian air seduhan kunyit memberikan pengaruh yang berbeda nyata terhadap pertambahan bobot badan dua strain ayam broiler. Selanjutnya Nurhayati et al. (2015) melaporkan bahwa penambahan produk fermentasi kunyit sebanyak $10 \%$ didalam ransum ayam broiler dapat meningkatkan pertambahan bobot badan. Namun demikian hasil penelitian ini sesuai dengan dengan yang dilaporkan oleh beberapa peneliti sebelumnya. Yuwanta (2004), melaporkan bahwa tidak ada pengaruh terhadap konsumsi ransum, konsumsi air minum, produktifitas telur hen day, berat telur dan konversi pada ayam petelur yang diberi tambahan air rebusan daun sirih ke dalam air minum. Hutabarat et al. (2014) melaporkan bahwa pemberian tepung kunyit maupun temulawak tidak berpengaruh terhadaap pertambahan bobot badan ayam broiler. Selanjutnya Pratikno (2010) juga menyimpulkan menyatakan bahwa dosis ekstrak kunyit tidak mempengaruhi bobot badan akhir ayam broiler. Tidak berpengaruhnya pemberian larutan sirih terhadap bobot badan akhir pada penelitian ini sesuai dengan hasil penelitian Haryuni et al. (2017) yang menyimpulkan dengan penambahan $7.5 \mathrm{ml}$ sampai $12,5 \mathrm{ml}$ jus sirih tidak berpengaruh terhadap konsumsi pakan, HDP, berat telur dan FCR ayam petelur.

Beberapa faktor yang diduga penyebab tidak berpengaruhnya pemberian ekstrak daun kunyit maupun daun sirih atau kombinasi keduanya terhadap bobot badan akhir diantarany diduga dosis perlakuan yang diberikan belum mencukupi untuk mempengaruhi proses metabolisme didalam saluran pencernaan sehingga efeknya tidak berpengaruh terhadap bobot badan ayam broiler. Ketidakcukupan dosis tersebut berdampak terhadap kandungan zat bioaktif khususnya curcumin yang bersifat antibakteri dan kandungan atsiri pada daun sirih belum optimal untuk mempengaruhi saluran pencernaan guna meningkatkan metabolisme tubuh. Dugaan lainnya adalah bahwa proses absorbsi kurkuminoid dan minyak atsiri yang ada terdapat pada kunyit belum berjalan secara efektif didalam system pencernaan, sehingga tidak dapat mempengaruhi metabolisme (Pratikno, 2010).

\section{Bobot karkas}

Rataan bobot karkas (g/ekor) ayam broiler yang diberi perlakuan kunyit dan daun sirih serta kombinasi keduanya di dalam air minum selama penelitian disajikan pada Tabel 3. Sebagaimana yang ditampilkan pada Tabel 3, kisaran bobot karkas ayam adalah 773,50 sampai 813,50 g/ekor. Berdasarkan hasil analisis sidik ragam, pemberian air minum dengan larutan kunyit dan daun sirih maupun kombinasi keduanya tidak berpengaruh nyata $(\mathrm{P}>0,05)$ terhadap bobot karkas ayam broiler. Sudrajat et al. (2015) melaporkan bahwa pemberian larutan air sirih didalam air minum tidak berpengaruh terhadap kecernaan bahan kering ayam broiler jantan. Hal ini diduga disebabkan oleh bobot badan akhir pada penelitian ini tidak berpengaruh nyata dipengaruhi perlakuan.

Menurut Haroen (2003) bahwa antara bobot karkas dengan pertambahan bobot badan memiliki kaitan yang sangat erat yakni hubungan yang berbanding lurus. Ditambahkan oleh Marwandana (2012) apabila bobot badan tidak berbeda nyata maka bobot karkas juga tidak berbeda. Hasil penelitian ini sesuai dengan yang dilaporkan Syam (2015) yang melaporkan bahwa pengaruh penambahan larutan beberapa herbal termasuk kunyit menghasilkan bobot karkas tertinggi dibandingkan dengan kontrol. Beberapa hasil penelitian tersebut mengindikasikan bahwa zat bioaktif yang terdapat dalam dalam larutan herbal memiliki pengaruh positif terhadap beberapa parameter performans seperti karkas (Agustina, 2006).

Tabel 3. Rataan bobot karkas ayam broiler umur 28 hari yang diberi larutan kunyit, rebusan sirih atau kombinasi keduanya (g/ekor)

\begin{tabular}{lc}
\hline Perlakuan (\%) & Bobot Karkas (g/ekor) \\
\hline Air Biasa (Kontrol) (P0) & $813,50 \pm 18,15$ \\
Air dengan LK 25\% (P1) & $814,38 \pm 63,76$ \\
Air dengan LS 25\% (P2) & $773,50 \pm 27,56$ \\
Air dengan LK dan LS 25\% (P3) & $786,30 \pm 31,87$ \\
\hline
\end{tabular}

Keterangan: - LK = Larutan Kunyit, LS = Larutan Sirih

- Data yang ditampilkan adalah Rataan \pm Standar Deviasi 
Ditambahkan oleh Riduwanto (2010) bahwa kunyit memiliki peran pada proses pencernaan didalam organ khususnya dalam meningkatkan metabolisme karbohidrat, lemak dan protein. Selanjutnya, Mide (2012) menyimpulkan bahwa pakan yang ditambahkan dengan tepung rimpang kunyit secara tidak langsung memberikan pengaruh terhadap konsumsi pakan dan absorbsi nutrisi makanan sehingga dapat menghasilkan produksi daging, persentase karkas daging akan meningkat.

\section{Persentase Karkas}

Rataan persentase karkas (\%) ayam ras pedaging yang diberi perlakuan kunyit dan daun sirih serta kombinasi keduanya di dalam air minum selama penelitian disajikan pada Tabel 4.

Tabel 4. Rataan persentase karkas ayam broiler umur 28 hari yang diberi larutan kunyit, rebusan sirih atau kombinasi keduanya (\%)

\begin{tabular}{lr}
\hline Perlakuan (\%) & Persentase karkas \\
\hline Air Biasa (Kontrol) (P0) & $67,54 \pm 1,17^{\mathrm{a}}$ \\
Air dengan LK 25\% (P1) & $63,08 \pm 3,07^{\mathrm{b}}$ \\
Air dengan LS 25\% (P2) & $63,36 \pm 2,09^{\mathrm{b}}$ \\
Air dengan LK dan LS 25\% (P3) & $63,77 \pm 2,01^{\mathrm{b}}$ \\
\hline
\end{tabular}

Keterangan: - LK = Larutan Kunyit, LS = Larutan Sirih

- Data yang ditampilkan adalah Rataan \pm Standar Deviasi

- Superskrip yang berbeda pada kolom yang sama menunjukkan pengaruh yang nyata $(\mathrm{P}<0,05)$.

Sebagaimana ditampilkan pada Tabel 4, persentase karkas ayam broiler dipengaruhi secara nyata $(\mathrm{P}<0,05)$ dengan perlakuan yang diberikan. Kisaranpersentase karkas antara 63,08-67,54\% yang diperoleh pada penelitian ini masih tergolong sesuai dengan standar persentase karkas ayam broiler. Menurut Siregar et al. (1980) bahwa rentang persentase karkas normal untuk ayam broiler adalah antara $60 \%$ sampai $75 \%$ dari berat badan.

Berdasarkan hasil uji lanjut DMRT menunjukkan bahwa persentase karkas ayam broiler perlakuan $\mathrm{P} 0$ berbeda nyata $(\mathrm{P}<0,05)$ dengan P1, P2 dan P3. Namun demikian, antara perlakuan P1, P2 dan P3 tidak berbeda nyata. Dari hasil yang diperoleh ini mengindifikasikan bahwa pemberian campuran larutan kunyit dan daun sirih serta kombinasi keduanya dalam air minum menyebabkan menurunnya persentase karkas ayam broiler.

\section{Bobot lemak abdominal}

Rataan bobot lemak abdominal ayam broiler yang diberi perlakuan kunyit dan daun sirih serta kombinasi keduanya di dalam air minum selama penelitian disajikan dalam Tabel 5 . Adapun kisaran rataan bobot lemak abdominal ayam broiler yang diperoleh pada penelitian ini adalah antara 19,00-20,00 g/ekor. Perlakuan P3 menghasilkan rataan bobot lemak abdominal tertinggi yakni 20,00 g/ekor, sedangkan P1 menghasilkan rataan bobot lemak terendah yakni 19,00 g/ekor.

Hasil analisis sidik ragam diperoleh bobot lemak abdominal ayam broiler tidak dipengaruhi $(\mathrm{P}>0,05)$ perlakuan yang diberikan. Walaupun tidak berbeda nyata, namun, perlakuan P1 memberikan bobot lemak abdominal yang paling rendah yakni sebesar 19,00 g/ekor. Rataan bobot lemak abdominal yang diperoleh pada penelitian ini lebih rendah dengan laporan Tama et al. (2017) bobot lemak abdominal ayam broiler dengan perasan air kunyit dosis

Tabel 5. Rataan bobot lemak abdominal ayam broiler umur 28 hari yang diberi larutan kunyit, rebusan sirih atau kombinasi keduanya (g/ekor)

\begin{tabular}{lr}
\hline Perlakuan (\%) & Bobot lemak abdominal \\
\hline Air Biasa (Kontrol) (P0) & $19,38 \pm 2,43$ \\
Air dengan LK 25\% (P1) & $19,00 \pm 2,55$ \\
Air dengan LS 25\% (P2) & $19,88 \pm 1,80$ \\
Air dengan LK dan LS 25\% (P3) & $20,00 \pm 1,29$ \\
\hline
\end{tabular}

Keterangan: - LK = Larutan Kunyit, LS = Larutan Sirih

- Data yang ditampilkan adalah Rataan \pm Standar Deviasi 
$20,83 \mathrm{~g} / \mathrm{l}$ adalah sebesar 27,33 g/ekor. Hal ini diduga dipengaruhi kandungan kurkumin dan minyak atsiri pada kunyit dapat meningkatkan produksi dan sekresi empedu. Peningkatan sekresi empedu didalam duodenum untuk eksresi asam empedu yang seterusnya akan membantu pemecahan lemak kedalam feses yang berakibat lemak didalam tubuh juga berkurang (Mide, 2012). Menurut Tama et al. (2017) minyak atsiri, kurkumin dan penol dapat membantu proses hidrolisis trigliserida (lemak).
Menurut Tama et al. (2017) bahwa proses hidrolisis lemak dapat berjalan dengan baik dan efektif jika lemak yang dikonsumsi dapat digunakan ayam broiler untuk melakukan metabolisme dan pertumbuhan sehingga terhindar dari penimbunan lemak yang tinggi.

\section{Persentase Lemak Abdominal}

Rataan persentase lemak abdominal ayam broiler yang diberi perlakuan kunyit dan daun sirih di dalam air minum serta kombinasi keduanya selama penelitian disajikan dalam Tabel 6.

Tabel 6. Rataan persentase lemak abdominal ayam broiler umur 28 hari yang diberi larutan kunyit, rebusan sirih atau kombinasi keduanya (\%)

\begin{tabular}{lc}
\hline Perlakuan (\%) & Persentase Lemak Abdominal (\%) \\
\hline Air Biasa (Kontrol) (P0) & $2,34 \pm 0,34$ \\
Air dengan LK 25\% (P1) & $2,25 \pm 0,39$ \\
Air dengan LS 25\% (P2) & $2,56 \pm 0,21$ \\
Air dengan LK dan LS 25\% (P3) & $2,67 \pm 0,31$ \\
\hline
\end{tabular}

Keterangan: - LK = Larutan Kunyit, LS = Larutan Sirih

- Data yang ditampilkan adalah Rataan \pm Standar Deviasi

Hasil analisis sidik ragam diperoleh bahwa perlakuan yang diberikan memberikan pengaruh yang tidak berbeda nyata $(\mathrm{P}>0,05)$ terhadap persentase lemak abdominal ayam broiler.

Kisaran rataan persentase lemak abdominal ayam broiler pada penelitian ini masih dalam kategori kisaran normal yaitu berkisar 2,252,67\%. Grifiths et al. (1977) melaporkan bahwa persentase lemak abdominal ayam broiler yakni 2,22-3,19\% dari bobot badan. Ditambahkan oleh Salam (2013) bahwa kisaran persentase lemak abdominal karkas ayam broiler adalah $0,73 \%$ sampai $3,78 \%$. Sebagaimana yang ditampilkan pada Tabel 6 bahwa persentase lemak abdominal yang paling rendah adalah pada perlakuan P1. Sementara itu, perlakuan P2 dan P3 menghasilkan persentase lemak abdominal yang cenderung meningkat.

Terjadinya penurunan persentase lemak abdominal ayam broiler pada perlakuan P1 diduga karena dipengaruhi oleh kandungan kurkumin dan yang terdapat dalam larutan kunyit. Menurut Darwis et al. (1991) bahwa peran kurkumin dapat sebagai antibakteri dan sekaligus merangsang dinding kantung empedu, dimana cairan empedu tersebut memiliki peran dalam memperlancar metabolisme lemak. Kandungan cairan empedu yakni cairan garam berwarna kuning kehijauan yang didalamnya terkandung kolesterol, fosfolipid, lesitin dan pigmen empedu.. Didalam usus halus, cairan garam tersebut akan bercampur dengan lemak membentuk micelles yang seterusnya dapat mengurangi permukaan lemak dan gerakan mencampur pada saluran pencernaan secara bertahap akan memecah globules lemak menjadi partikel yang halus yang berakibat lemak lebih dapat dicerna dan akan berkurang. Hasil penelitian ini sejalan dengan yang dilaporkan Arifin (2003) bahwa pemberian pellet kunyit pada ayam broiler dapat menurunkan persentase lemak abdominal.

\section{KESIMPULAN}

Penambahan ekstrak kunyit atau sirih atau campuran keduanya pada level $25 \%$ di dalam air minum belum dapat meningkatkan bobot badan akhir,bobot karkas dan persentase karkas dan belum mampu meminimalkan bobot lemak abdominal dan persentase lemak abdominal ayam broiler.

\section{DAFTAR PUSTAKA}

Adi, R. 2009. Efektifivitas Betain Pada Pakan Ayam Broiler Rendah Metionin Berdasarkan Parameter Berat Badan dan Karkas. Skripsi. Fakultas Pertanian Universitas Sebelas Maret. Solo.

Adi, R. 2009. Efektifivitas Betain Pada Pakan Ayam Broiler Rendah Metionin Berdasarkan Parameter Berat Badan dan 
Karkas. Skripsi. Fakultas Pertanian Universitas Sebelas Maret. Solo.

Agustina, L. 2006. Penggunaan ramuan herbal sebagai feed additive untuk meningkatkan performans Broiler. Prosiding Lokakarya Nasional Inovasi Teknologi dalam mendukung Usaha Ternak Unggas Berdaya Saing. Pusat Penelitian dan Pengembangan Peternakan, Bogor.

Amrullah, I. K. 2003. Nutrisi Ayam Petelur Seri Beternak Mandiri. Cetakan Pertama. Penerbit Lembaga Satu Gunungbudi. Bogor.

Anggorodi, R. 1985. Kemajuan Mutakhir dalam Ilmu Makanan Ternak Unggas. UI Press. Jakarta.

Anggorodi, R. 1990. Ilmu Kesehatan Ternak Umum. PT.Gramedia, Jakarta.

Anonim. 2013. Pemanfaatan Daun Sirih. http : // shoreaaugustaa. blogspot. Com / 2013 / 12 / pemanfaatan daun sirih. html. (10 November 2014).

Anonim. 2014a. Ciri-Ciri Tanaman Sirih serta Khasiat dan Manfaatnya. http : // www. tanobat. Com / sirih ciri - ciri tanaman sirih serta khasiat dan manfaatnya.html. (5 Agustus 2015).

Anonim. 2014b. Daun Sirih. http : // jojontor. blogspot. Com / 2014 / 01 / karya ilmiah tentang daun sirih. html. (5 Agustus 2015).

Arifin, Z. 2003. Pengaruh Pemberian Pellet Kunyit (Curcuma domestica Val) terhadap Penampilan Karkas dan Nisbah Daging Tulang Karkas Ayam Pedaging. Skripsi. Fakultas Peternakan Universitas Diponegoro. Semarang

Chasanah. N. 2009. Pengaruh Suplementasi Tepung Bawang Putih dan Tepung Temulawak Terhadap Komposisi Kimia dan Kadar Kolestrol Ayam Broiler. Skripsi. Fakultas Peternakan. Universitas Universitas Gadjah Mada. Yogyakarta.

Darwis, S. N., A. B. D. Modjo Indo dan S. Hasiyah. 1991. Tanaman Obat Familia Zingiberaceae. Badan Penelitian dan Pengembangan Pertanian Industri. Bogor.

Fontana, E. A., D. Weaver Jr, D. M. Denbaow and B. A. Watkins. 1993. Early feed restricition of broiler : Effect on abdominal fad pad, liver, and gizzard weight, fat deposition and carcass composition. Poult. Sci. 72 : 243-250.

Haryuni, N., E. Widodo and E. Sudjaarwo. Efek Penambahan Jus dan Daun Sirih (Piper bettle Linn) Sebagai Aditif Pakan Terhadap Peforma Ayam Petelur. Brillian: Jurnal Riset dan Konseptual. Vol: 2:4; 429-433.

Hernani dan S. Yuliani. 1991. Peranan Sirih Sebagai Obat Tradisional. Warta Tumbuhan Obat Indonesia 1 (1): 13-14.

Hidayatiningtyas, P. 2008. Perbandingan Efek Antibakteri Air Seduhan Daun Sirih (Piper bettle Linn) terhadap Streptococcus Mutans pada Waktu Kontak dan Konsentrasi yang Berbeda. Skripsi, Fakultas Kedokteran Universitas Diponegoro Semarang.

Juliantina, F., D.A. Citra, B. Nirwani, T. Nurmasitoh, E. T. Bowo. 2009. Manfaat Sirih Merah (Piper crocatum) sebagai Agen Antibakterial terhadap Bakteri Gram Positif dan Gram Negatif. Jurnal Kedokteran dan Kesehatan Indonesia 1(1) : 12-20

Kartadisastra, H. R. 1994. Pengelolaan Pakan Ayam. Kanisius. Yogyakarta. 25 Oktober 2015.

Kusumaningrum D. 2008. Pemetaan Karakteristik Komponen Polifenol untuk mencegah Kerusakannya pada Minuman The Ready to Drink (RTD) [Skripsi]. Bogor.Institut Pertanian Bogor.

Liang, O.B., Y. Apsartom, Y. Widjaya, dan Y. Puspa. 1985. Beberapa Aspek Isolasi, Identifikasi dan Penggunaan Komponenkomponen Curcuma xanthoriza Roxb Dan Curcuma domestica Val. Proseding Simposium Nasional Temulawak. Lembaga Penelitian Universitas Padjajaran. Bandung.

Mahendra, B. 2005. 13 Jenis Tanaman Obat Ampuh. Penebar Swadaya. Jakarta.

Moeljanto, R.D., Mulyono. 2003. Khasiat dan manfaat daun sirih, obat mujarab dari masa ke masa. Agromedia Pustaka 7-11, Yogyakarta. 
Rahardjo, M. dan O., Rostiana. 2005. Budidaya Tanaman Kunyit. Balai Penelitian Tanaman Obat dan Aromatika. Sirkuler No.11. p.1-7. http://www.balittro.go.id 1Mei 2015.

Rasyaf, M. 1992. Beternak Ayam Broiler. Kanisisus. Yogyakarta..

Retnani. Y. W. Widiarti, I. Amiroh, L. Herawati dan K.B. Satoto. 2009. Daya simpan dan palatabilitas wafer Ransum Komplit Pucuk dan Ampas Tebu untuk sapi pedet. Media Peternakan 32 (2) :130-136.

Rose, S. P. 1997. Prinsiples of poultry Sciences. Harper Adams Agricultural Collag. London

Rosman, R dan S. Suhirman. 2006. Sirih Tanaman Obat Yang Perlu Mendapat Sentuhan Tekonologi Budaya. Warta Penelitian dan Pengembangan Tanaman Industri 12 (1): 13-15.

Rukmana, R. 1994. Kunyit. Kanisius. Yogyakarta.

Scott, M. L., M Nesheim, and R.J Young. 1992. Nutrition of The Chiken. FifthEd. Scott, M. L. And Associates. Ithaca. New York.

Soedibyo, M. 1997. Alam Sumber Kesehatan Manfaat dan Kegunaan. Jakarta: Balai Pustaka

Sumiati, T. dan I. K. Adnyana. 2004. Kunyit, Si Kuning yang kaya manfaat. http ://www.pikiranrakyat.com/cakrawala/lainnya02.htm Desember 2006].

Syam, M. 2015. Analisis Berat Dan Kualitas Karkas Ayam Broiler Yang Diberikan Jamu Probiotik Dan Tanaman Herbal Melalui Air Minum. Jurnal Galung Tropika, 4(2): 7480 .

Tantalo, S. 2007. Perbandingan Performans Dua Strain Broiler Yang Mengonsumsi Air
Kunyit. Jurnal Ilmiah Fakultas Pertanian Universitas Lampung.

Tantalo, S. 2007. Perbandingan Performans Dua Strain Broiler Yang Mengonsumsi Air Kunyit. Jurnal Ilmiah Fakultas Pertanian Universitas Lampung.

Tjitrosoepomo. 2004. Taksonomi Tumbuhan Obat-Obatan. Gadjah Mada University Press: yogyakarta.

Triana, A. 2014. Minyak Atsiri Daun Sirih Merah (Piper crocatum) sebagai Pengawet alami pada Ikan Teri (Stolephorus indicus) Essential Oil Of Red Betel Leaves (Piper crocatum) As A Natural Preservative Anchovies (Stolephorus indicus). Skripsi. Jurusan Peternakan. Fakultas Peternakan. Universitas Brawijaya. Malang.

Tze-Pin Ng . 2003. Kunyit, Herbal Penguat Daya Ingat (Anti Alzheimer). NUS. Https : // cinta herbal. Word press. Com / 2009 / 04 / $16 /$ kunyit herbal penguat daya ingat anti Alzheimer /. 2 September 2015.

Wahyu, J. 1992. Ilmu nutrisi unggas. Gadjah Mada University Press. Yogyakarta.

Wijayakusuma, M. H. 2005. Kunyit dan Temulawak untuk Mencegah Flu Burung. Http://www.republika.co.id. 1 September 2015.

Winarto, W.P. 2003. Khasiat dan Manfaat Pegagan. Tanaman Penambah Daya Ingat. Agromedia Pustaka. Jakarta. Hal 23.

Yuningsih. 2004, Keberadaan residu antibiotika dalam produk peternakan (susu dan daging), Di Dalam: Lokakarya Nasional Keamanan Pangan Produk Peternakan,Bogor: Balai Penelitian Veteriner, Hal. 48-55

Yuwanta, T., 2004. Dasar Ternak Unggas. Kanisius. Yogyakarta. 